Making sense of employer collectivism

The case of Danish wage bargaining under recession

Ibsen, Christian Lyhne

Published in:

Journal of Industrial Relations

DOI:

$10.1177 / 0022185616650985$

Publication date:

2016

Document version

Peer reviewed version

Citation for published version (APA):

Ibsen, C. L. (2016). Making sense of employer collectivism: The case of Danish wage bargaining under recession. Journal of Industrial Relations, 58(5), 669-687. https://doi.org/10.1177/0022185616650985 


\title{
Making sense of employer collectivism - The case of Danish wage bargaining under recession
}

\author{
Christian Lyhne Ibsen \\ University of Copenhagen, Denmark \\ forthcoming in Journal of Industrial Relations \\ (version 2 of article)
}

\begin{abstract}
This conceptual paper argues that preferences of employers for collective action cannot be reduced to rational actors making decisions based on market structures or institutional logics. Both markets and institutions are inherently ambiguous and employers therefore have to settle for plausible - rather than accurate - rational strategies among many alternatives through so-called sensemaking. Sensemaking refers to the process by which employers continuously make sense of their competitive environment by building causal stories of competitive advantages. The paper therefore tries to provide a better understanding of how preferences for collectivism are formed, sustained and potentially changed by identifying dominant and competing stories that either reinforce or challenge preferences for collectivism. Hereby, the paper fills a theoretical, empirical and methodological void in studies that allude to the ambiguous role of markets and institutions but do not study how actors deal with this ambiguity. The sensemaking concept is illustrated with an analysis of wage bargaining in Denmark during the recent recession when Danish labour cost competitiveness was in a deplorable state. However, unlike countries in similar situations e.g. Finland and Sweden, Danish employers retained coordinated industry-level bargaining system, which makes it an interesting paradox to study from the vantage point of sensemaking.
\end{abstract}




\section{Introduction}

While collective bargaining at varying pace has eroded in many countries in the recent four decades, employers still act collectively. This conceptual paper argues that the preferences employers for collective action cannot be reduced to rational actors making decisions based on market structures or institutional logics. Both markets and institutions are inherently ambiguous (Parsons, 2007; Streeck and Thelen, 2005) and employers therefore have to settle for plausible - rather than accurate - rational strategies among many alternatives through so-called sensemaking (Weick, 1995; Fligstein and McAdam, 2012). Sensemaking refers to the process by which employers continuously make sense of their competitive environment by building causal stories of competitive advantages (Porac et al., 1989).

The paper therefore tries to provide a better understanding of how preferences for collectivism are formed, sustained and potentially changed by identifying dominant and competing stories that either reinforce or challenge preferences for collectivism. The sensemaking concept comes from organization studies and sociological institutionalism and provides a novel theoretical micro-foundation for the study of employer collectivism that couches the empirical investigation at the company level. Hereby, the paper fills a theoretical and methodological void in studies that allude to the ambiguous role of markets and institutions but do not study how actors deal with this ambiguity. 
The sensemaking concept is illustrated with an analysis of wage bargaining in Denmark during the recent recession. In Denmark, multi-employer collective agreements for many decades have served to on one hand take wages out of competition and on the other moderate wages. The Danish wage bargaining systems therefore constitutes a clear example of employer collective action (Madsen et al., 2016). During the recent recession, however, Danish labour cost competitiveness was in a deplorable state, raising doubts about the wage moderation function. However, in contrast to similar countries in similar situations like Finland and Sweden, where governments and social partners questioned their systems and reformed them to restore moderation of wages, Danish employers stuck to their coordinated industry-level bargaining system. This stability - despite loss of cost competitiveness and major job losses - makes Denmark an interesting case to study from the vantage point of sensemaking.

The rest of the paper is divided into four sections. In the first section, employer collectivism is generally defined and the dominant explanations for employer collectivism are presented. It is argued that these explanations can be divided into two; market-based and institutionalist explanations. In the second section of the paper, the concept of sensemaking is developed by addressing the question of how employers subscribe to stories about competitive advantage stemming from employer collectivism. In the third section, I illustrate how the sensemaking concept can be used in the cases of how employers in Denmark have made sense of their employer associations during 
economic recession. The fourth section concludes with a reflection of how the sensemaking concept brings analytical value to the study of employer collectivism.

\section{Explaining employer collectivism}

Conventional accounts of employer collectivism depart from the assumption that employers will cooperate when it is in their economic interest to do so. The self-interest in cooperation between potential competitors originates for three general reasons (Schmitter and Streeck, 1999: 12; Windmuller and Gladstone, 1984). Firstly, employers cooperate to control forces in markets that are harmful to the incumbent companies like cut-throat price competition, access of new market players, control of input costs. Secondly, employers cooperate to countervail the power of organised labour to secure stable and affordable labour supply (Barry and Wilkinson, 2011). Thirdly, employers cooperate to countervail popular demand for legal regulation and taxation of companies especially in democracies (ibid.). Collectivism between employers is, however, subject to free-rider problems when employers enjoy public goods without contributing to the production thereof (Olson, 1965). Therefore, while these three interests are general, we need more fine-grained explanations to account for particular instances of employer collective action.

In my account of different explanations for employer collectivism, I depart from Parsons' distinction between market-structural, institutional and ideational 
explanations $^{1}$ (2007). The two former are based on rationalist theory of human agency, but attribute causal powers to either market-structures or man-made institutions, respectively. The third explanation is based on how actors make sense of their environment and attributes causal power to man-made meaning structures. My account thus distinguishes institutions - that constrain and enable rational actors by providing them incentive structures - from meaning structures - that equip actors with enabling and constraining interpretations of the world ${ }^{2}$. The distinction is vital because it yields two different types of analysis: 1) analysis of institutions' mediating effect on the behaviour of rational agents, and 2) analysis the sensemaking behind behaviour of agents that may or may not be 'rational' in a material sense. As I will show, the second type of analysis relies on demonstrating that neither market structure, nor institutions predetermined sensemaking, i.e. that meaning structures behind an action cannot be reduced to rational acts based on market structures or institutional incentive structures (Parsons, 2007: 13). This is a tall order, but also one that corresponds well with recent work on institutional change and ambiguity (e.g. Streeck \& Thelen, 2005; Borrás and Seabrooke, 2015).

\footnotetext{
${ }^{1}$ I leave out psychological explanations which are also included in Parsons mapping: 'Psychological claims assert that people perceive the world around them through hard-wired instincts, affective commitments, and/or cognitive shortcuts' (Parsons, 2007: 13).

${ }^{2}$ Many scholars in the sociological institutionalist camp would argue that they also study institutions. To be clear, distinguishing institutional from ideational explanations is about identifying more precisely the causal forces in different theories. Following Parsons, it can be said that the '... Ideational explanation addresses the subset of institutions (practices, symbols, norms, grammars, models, identities) through which people interpret their world. (2007: 100)'. Indeed, early institutionalist Veblen argues that institutions were the prevalent habits of thought (1899).
} 
In market-structural explanations employers' interest in cooperating depend on their positions in market structures, that is, the resource allocation and relationships between companies (Parsons, 2007). Scholars will, however, emphasise different structures. Windmuller and Gladstone (1984) and Schmitter and Streeck (1999) for example posit that company size matters. One market leader might not need collectivism while a few larger companies cannot go-it-alone. The few larger companies might therefore take on the cost of cooperation and sanction that smaller actors do not free-ride. Heterogeneity of company size might actually help the production and sustainment of employer collectivism. Some scholars, conversely, argue that collectivism can be hampered by employer heterogeneity. For example, if companies have different mixes of capital, labour and raw materials, this might give them different preferences for collectivism on labour matters. For example, Swenson (2002) argues that employers under fierce lowcost competition and employing low-skilled workers benefit from collective bargaining as it takes wages out of competition. Conversely, employers in high-end manufacturing and exposed to international competition, have an interest in flexible wage-setting to attract high-skilled labour but must avoid cost-push externalities from other industries due to foreign competition. Finally, employers that are not in competition with foreign companies and employ highly skilled workers can easily pass on pay hikes to price increases for consumers and therefore might prefer company level bargaining. 
Internationalisation of markets might erode the preference for national employer association as employers no longer direct their business towards national markets (Katz, 1993). In this vein, Kitschelt et al. (1999) argue that national employer collectivism in labour markets will eventually wither away as they national collectivism no longer fits the markets, in which companies operate.

Institutionalist explanations, conversely, stress that man-made rules, norms and procedures mediate market structures by providing specific logics for behaviour (Hall and Taylor, 1996; Parsons, 2007). This explanation suggests that institutions either promote or demote collectivism by providing incentives for collectivism. And as institutions give positive feedback to existing logic of actions they produce path dependency despite changes to market structures, e.g. internationalization (Pierson, 2004; Tolliday \& Zeitlin, 1991).

Scholars, however, disagree about which institutions are decisive. For example, Korpi (2006) argues that employers develop a preference for cooperation when forced to by strong trade unions that have control over labour supply. This logic is central to industrial relations scholars (Windmuller and Gladstone, 1984; Sisson, 1987; Sheldon et al., 2014). Institutions that promote strong unions, such as the Ghent-system and lax regulation of industrial action, are therefore conducive to employer collectivism (Traxler, 2007). Conversely, the varieties of capitalism-literature (Hall and Soskice, 2001) argues that employers in certain countries have a first-best preference for 
cooperation due to the competitive advantage they derive from institutionalized public goods, such as training funds and wage moderation in collective bargaining. Moreover, employment protection legislation might help employers in overcoming market failures in skill formation (Estevez-Abe et al. 2001) as it secures a return on investment on skills when poaching becomes harder.

Martin and Swank (2012) argue that employers build macro-level coordination capability due to the parliamentary system of a nation and the state structure. In multiparty systems, business never found a strong Conservative party to represent their interest and employers therefore had to build political clout through associations to counter-balance labour and agriculture. Conversely, in two-party systems, strong conservative parties represented business vis-à-vis labour and agriculture and the need for strong business associations did not materialise. Moreover, in unitary states employer associations had an integrated macro-political arena on which to coordinate interests, as opposed to federalist systems where the political locus is dispersed between federal and state level.

The above sketched theories are based on rational employers cooperating according to market positions or institutional incentives. Wailes et al. (2003) have argued for an integration of institutional and interest-based theories, which retains institutional insights but examines the role interests play in shaping the relationship between international economic change and national/institutional patterns of industrial relations. 
Mapping both institutions and interests for explanatory purposes is important. However, I argue that market-structures and institutions are ambiguous and because of ambiguity, preferences are not self-evident for employers (cf. Tolliday \& Zeitlin, 1991; Borrás and Seabrooke, 2015). Ambiguity stems from two sources. First, there is an issue of intersectionality. Actors pertain to various institutional domains, giving actors some freedom to choose between different institutional logics (Friedland and Alford, 1991; Weber and Glynn, 2006). The institutional domains pertaining to membership of an employer association can range widely from wage bargaining, competition policy, environmental lobbyism, vocational education and training (VET) provisions, to fiscal policy etc. The logic of action in each domain may or may not coincide depending on the specific situation. For example, the institutional domain of wage bargaining and VET might coincide when VET-provision is collective but wage bargaining takes place at company level. Employers fearing poaching through local wage premium on skills might start to question the viability of collective VET-provision. However, this coupling of institutional domains by an employer is not automatic but requires active identification of the problem of poaching due to company-level wage bargaining (as opposed to poaching in general) and suggestions of solutions that may or may not be of a collective nature. This is where sensemaking comes in.

Market structures - and therefore material interests - are also characterised by intersectionality. Consider the long list of variables expected to affect the associative 
potential of a population of employers in Schmitter and Streeck (1999: 24-30): Number of employers; equality of resources; degree of competition; degree of interdependence; heterogeneity of factor inputs/outputs; company turnover; profitability/growth; and social interactions/cohesion. These variables can be measured but for owners they need to be factored against each other, because collectivism might be rational in one structure, but irrational in another. Much of this - I argue - will depend on what institutional and structural elements are deemed as most important to the company. In turn, these choices will have consequences for the decisions of 1) becoming a member of the association and 2) what the membership is supposed to deliver.

Second, there is an issue of change. The choice to be a member of an association might be stable over time but it is not permanent, nor is the content of the membership, i.e. what associations do for their members. In the market-based explanation, change occurs due to market structures changing. Responses to structural changes are, however, not self-evident (Blyth, 2003) and very similar structural changes have been dealt with remarkably differently by similar actors - there is a gap between structural change and actors' responses. The institutionalist explanation goes a long way in filling this gap by referring to specific institutions that shape how employers filter and respond to structural changes. However, institutions themselves change and rules are often ambiguous (Streeck and Thelen, 2005), not least due to intersectionality. 
Some scholars have introduced discourses or ideas as meaning structures to explain both stability and shifts in employer preferences (cf. Schmidt, 2010). For example, Frege shows how national discourse of democracy at work produce different institutions for industrial democracy (2005). However, this approach often operates at the macrolevel, e.g. the transition from Keynesianism to neo-liberalism (Campbell \& Pedersen, 2001) and is therefore insensitive to how actors actively use ideas differentially. The issues of intersectionality and change call for a more agency-based view of how markets and institutions are framed by meaning structures, i.e. how actors make sense of markets and institutions (Carstensen, 2010). To be sure, this call does not negate that market structures, institutions or macro-ideas are important in explaining employer collectivism - they clearly are. But these explanations cannot tell us much about how actors continuously and strategically solve ambiguity by making sense of markets and institutions. To this end, macro-ideas can serve a normative and/or cognitive repertoire of making sense of reality, but these ideas do not determine the sensemaking process and are often too 'distant' to influence meso- and micro level preference formation.

\section{Introducing sensemaking}

Employers and their managers continuously rationalize their actions in relation to their competitors and other stakeholders (Porac et al,. 1989). The framework for sensemaking analysis of employer collectivism focuses on 1) the salient cues about competitive 
advantage in relation to employer collectivism, and 2) how these cues labelled, categorized and related to each other into dominant and/or competing stories (Weick et al., 2005). Cues are understood as signals from the environment, e.g. from competitors, customers or suppliers about how the company is doing. A story is primarily cognitive as it develops a causal explanation of why an outcome occurs. To this end, macro-ideas are instrumental references as they typically involve models of cause-effect relationships (March, 2010). Also, managerial 'frames of reference' based on unitarist or pluralists attitudes might be used by employers (cf. Foster et al. 2011). As such, employers engage in activities similar to social scientists that work within certain causal universes that link certain conditions with certain outcomes and sometimes revise both the conditions and the outcomes of interest.

For our purposes, the story is about how employer collectivism causes competitive advantage - or not - for the company (March, 2010). An example of the former could be: 'we share the cost of training collectively because it funds training we otherwise would not get'. An example of the latter could be: 'we are paying too much to training funds compared to other members of the employer association'. These two stories are equally possible in one particular market structure and institutional setting and competing stories could indeed be likely due to intersectionality, which underlines the salience of sensemaking for studies of employer collectivism. 
If employers interpret new cues from their environment using the dominant story, the preference for collectivism is reinforced. This process is what Borrás and Seabrooke (2015:10) call 'belonging' - that is retrospective replication-based sensemaking, which refers to creation of narratives that '... explain what happened in terms of cues and causal stories from embedded identities and social norms'. If, however, the collectivist story is challenged by the competing story (Näslund and Pemer, 2012) employer collectivism might be jeopardized. Competing stories can emerge when cues are labelled or categorized differently from the dominant story. While external shocks are conducive to competing stories, the process can also occur by what Borrás and Seabrooke (2015: 11) call 'search systems' - that is prospective, abstraction-based sensemaking, which refers to systems in organizations that create '... an analytical framework that identifies and organizes important information in a future-oriented manner to help address organizational and institutional uncertainties'. By this manner, companies might constantly be questioning employer collectivism in an organised system.

While Weick's concept of sensemaking is useful and addresses the interactive process of sensemaking between actors, it underplays the political dynamics of sensemaking due to its intra-organisational focus. As Tolliday and Zeitlin (1991: 21) argue, employer collectivism is never a simple aggregation of objective interest - collectivism must be politically constructed. The work of Fligstein (2001) and his work with McAdam 
(Fligstein and McAdam, 2012) complements well in this regard because it combines sensemaking with the emergence, reproduction and transformation of local social orders such as the institutionalised cooperation between employers in labour markets. For Fligstein and McAdam, the issue of local social orders - or strategic action fields as they call them (ibid.: 9) - consist of actors who interact on the basis of more or less shared understandings of: 1) the purpose of the field, that is, what is at stake in the interaction, 2) who the powerful actors in the field are; 3) what the rules of the game in the field are; and 4) what the other actors in the field are doing (ibid.: 11). These understandings are not consensual, but ambiguous and depend on the position of the actor in the field. Incumbent actors dominate the field and are usually resourceful actors that benefit from the rules of the field, while challengers possess less resources and are at a disadvantage from the rules. Moreover, incumbents and challengers will typically differ in how they view the legitimacy of these understandings - incumbents believing that the shared understandings are legitimate and just, while the challengers believe them to be stigmatizing and unjust. Nevertheless, challengers gain from the being part of the field, at least in the sense that being outside of it is not an option.

In contrast to formal institutionalism that focus on power-relations through the lens of rule-markers and rule-takers (Streeck and Thelen, 2005), Fligstein and McAdam argue that incumbents and challengers are constantly engaged in a battle over sensemaking in their field. This does not mean fluid power-relations, as the incumbents hold 
advantageous positions to control sensemaking in the field, but it does mean that there is 'substantial latitude for routine jockeying and piecemeal change in the positions that actors occupy' (Fligstein and McAdam, 2012: 12). By relabelling and re-categorizing cues from the environment, one actor can suddenly be promoted or relegated in the field, e.g. when the work organisation of one challenger company is heralded as a source of competitive advantage vis-à-vis the incumbent or a bargaining level is viewed as outdated by some employers. Alternatively, new coalitions between challengers can arise that threaten the position of incumbents. Incumbents can resist these strategies either through resource-dependence measures or by counter-coalition making, hereby reproducing the positions of the field. In this regard, sensemaking plays a great part in mobilising support for the incumbents' understanding of what is at stake, who the powerful actors are, what the rules are, and what the other actors are doing. The last point is crucial in this regard. If incumbents can frame the actions of challengers as a danger to whole field, i.e. it will crumble if order is not restored, then it is likely that the incumbent can forge a powerful counter-coalition.

Due to ambiguity, the strategic actions between actors and coalitions of actors cannot be reduced to self-interested actions based on objective material interests or institutional logics. Rather, as Fligstein (2001) suggests, strategic actions are often motivated by a need for cooperation in the face of ambiguity. Cooperation - to be sure - can serve some actors better than others (Ibsen, 2015), but it always involves interaction that is 
framed by different degrees of authority, i.e. from direct authority to equal exchanges (Weber, 1978 cited in Fligstein, 2001). Fligstein (ibid.) suggests that some actors are better skilled than others to induce cooperation that is not based on direct authority. Skilled actors do so by providing a legitimate understanding of the situation, including what the problem and potential to this problem is. This skill can be based on agendasetting (Bachrach and Baratz, 1962), bricolage (Campbell, 2004), identifying interests rather than bargaining positions, mediation and brokering (Fisher and Ury, 1981) or by fixing a focal point in bargaining between actors (ibid.). These are all strategies in which sensemaking occurs by narrowing complex, ambiguous situations down to specific problems and solutions that reflect a certain causal story.

Sensemaking that involves collective action by employers is therefore a highly political process - a game - in which both social skills and material resources are activated. What is at stake is both the membership of employer associations and the content of this membership. As noted, membership rates might be very stable but the content of membership rarely is. In this game, employers will strategize and form coalitions in order to affect the course of employer associations. These processes are continuous and lead to incremental changes. In addition, external shocks such as international economic crisis cast existing causal stories about competitiveness in doubt giving substantial latitude for competing stories (Borrás and Seabrooke, 2015). The next section provide 
examples of sensemaking by Danish employers during the most recent economic recession.

\section{Employer collectivism in Denmark during recession}

This section presents some illustrative quotes from employer representatives in Denmark and how they made sense of employer collectivism during the recent recession. We focus on the private sector, as the public sector employers are almost 100 $\%$ covered by collective agreements and can solve collective action problems through legislation (Madsen et al., 2016). Danish companies typically join mixed associations, that is, where the employer and business functions are joined in one association. By design mixed associations make it possible that some companies are members for other reasons than the employer functions of the association. Indeed, Danish employer associations often allow for à la carte memberships in which the employer functions can be waived. The latest private sector estimates report a $52 \%$ employer density measured by representation of employed persons working for member companies. However, this density rate conceals that unorganised companies often join the relevant collective agreement for their economic area. The collective bargaining coverage is thus approximately $74 \%$ of private sector employees (DA, 2014). Around 70 percent of the wage-earners are members of trade unions (Ibsen et al., 2014). 
Since the beginning of the 1990s, Danish employer associations have merged extensively to reduce the number of associations that were typically based on trades and small industries. Today, 14 associations belong to the Confederation of Danish Employers (DA) which covers more than 28,000 private companies and 653.000 full time (equivalent) employees in manufacturing, retail, transport, services and construction (see table below). The finance sector employers covering 65.000 full-time employees are organised in the Employers' Association for the Financial Sector. The table below reports the main member associations of DA.

Table 1 here

The Danish collective bargaining system retains a high degree of coordination between employers on wage bargaining (Martin and Swank, 2012; Madsen et al. 2016). Multiemployer agreements set minimum wage levels for the covered companies within an industry. The agreements can stipulate the actual paid wage or be merely minimum wages which local bargaining agreements need to stay above. Figureless agreements also exist for salaried workers. Private sector bargaining is highly coordinated horizontally through patter-bargaining, where the exporting industries set the 'wage increase norm' for the sheltered industries (Ibsen, 2015). DI (see table 1) represents the 
exporting companies and is therefore the key employer association in the bargaining system. Moreover, it dwarfs the other associations due to its size.

Coordination on wages between employers solve two collective action problems between employers. Firstly, for the majority of workers within the DA-labour market, the multi-employer agreements set the floor and thus take out wages from competition between employers. As there is no statutory minimum wage in Denmark, collective agreements are therefore crucial for the internal regulation of wage competition between employers and thus constitute a clear example of employer collective action (Schmitter and Streeck, 1999). Secondly, coordination through pattern bargaining produces wage moderation. In small open economies, coordination is crucial since pay hikes in the sheltered sectors can be a cost-burden on exporting companies and eventually on the whole open economy (Traxler, 2007). In Denmark, a multi-tiered wage bargaining system exists in which framework agreements on terms and conditions set a norm for wage developments, but actual wages are decided at company level. By horizontally coordinating wage developments around the economic performance of exporting companies, other industries (and their employees) should overall be better off (however see Ibsen, 2015). 


\section{Employers' sensemaking during the recession}

Four general points can be made about the Danish economic recession of 2008-2014 (Goul Andersen, 2014; Ibsen, 2011). First, Denmark was in a very favourable economic situation at the outset of the crisis with very low levels of unemployment which put wage moderation to the test. Second, the negative impacts of the recession have been relatively more severe on key socioeconomic indicators than in other NorthernEuropean countries. Danish unemployment rates increased sharply from $4,1 \%$ in the last month of 2008 when recession hit Denmark to 7,2 the same time next year. Third, the bounce back of the Danish economy in terms of growth and unemployment has been somewhat slower than in other similar countries. Fourth and crucial for my purposes, failure to moderate wages were identified as a key cause of the poor performance of the Danish economy.

In terms of the two collective action problems between employers, coordination still served to put a floor under wages, but it had failed in moderating wages. In the years 2000-2008, unit labour costs in Denmark increased by 30 percentage points [year 2000=100] (Økonomi og Indenrigsministeriet, 2013: 30), which was substantially more than in competitor countries, notably Germany and Sweden. A key function of employer coordination was thus called seriously into question and a very plausible analysis of Danish wage developments during this period could read as follows: In the

Danish multi-tiered bargaining system with company level wage bargaining setting 
actual wages, employers that face strong local unions are ill-equipped to control wage developments - especially in times of low unemployment as was the case in Denmark before the crisis hit. Such an analysis of the problem could have spurred calls by employers - or their representatives - to create collective systems that control wage developments better, e.g. through incomes policies, or let the markets rule by decentralizing wages to the company level (Calmfors and Driffil, 1988).

These calls by employers were heard in similar countries with similar labour cost issues made sense differently than the Danish employers. As shown below, Finish employers had similar cost competitiveness problems, but clearly made sense of their situation in a very different way than their Danish colleagues. In Sweden, the employer confederation in 2010 argued that wage bargaining be decentralized from multi-employer agreements to company-level agreements. However, trade unions refused and a minor revision of the bargaining model kept the employers in multi-employer bargaining. Both small open economies like Denmark, Finland and Sweden were suffering from problems of labour cost competitiveness and huge job losses. Nonetheless, calls for bargaining centralization or decentralization to restore competitiveness never appeared in Denmark and real debates about the wage bargaining system among employers were largely absent despite the failure to moderate wages. Moreover, considering the powerful position of DI which represents companies in the export sector that suffered most from 
rising unit labour costs, it is surprising that this organization did not call the system for wage bargaining coordination into question.

Looking into the quotes of employer representatives might give an idea of the reasoning behind this absence. The following quotes are taken from 15 semi-structured interviews with employer representatives. The interviews revolved around issues of bargaining coordination and were conducted during 2010 and 2012. The quotes are chosen for their illustrative value and the purpose of the analysis is to show the potential of a sensemaking analysis - not give a full account of wage bargaining coordination during the recession.

In the following quote, a respondent uses cues about agreements on wages from the environment - in this case Germany - and relates these cues with specific labour market and institutional factors.

'There is no doubt that we take responsibility for the agreements that we make. And how does this responsibility relate to the fact that our costs are way too high - in manufacturing the unit labour cost is 30 DKK above the German? Well, it's a consequence of decentralized [multi-tiered] wage bargaining which is market-based and affected by alternative employment opportunities, taxation, labour supply shortages etc.'

The quote shows that cost competitiveness vis-à-vis Germany is highly salient, but the reasons for higher unit labour costs are market-based - labour supply shortage - with 
the addition of (high) taxation on income - not the institution of wage bargaining system per se. In previous crises, most notably during the 1970s, employers - and metalworking unions - rallied around a shift from confederate bargaining to industrybased bargaining with framework agreements on wages to curb wage inflation (Due et al. 1994). In contrast, the recent crisis - despite issues of cost competitiveness - did not spur calls for formal institutional changes of wage bargaining.

An underlying reason for letting wage bargaining 'off the hook' comes in the next quote where a respondent makes sense of the institution - multi-tiered wage bargaining:

'I'm a great supporter of this system. Because it's a system that shows where the weaknesses are. It's a system that show us all, including our politicians and the trade unions, what the effects of doing something stupid are... ... and it's far better that someone does something stupid in Nakskov [small city on the island of Lolland] and the company has to close, than if the LO and DA do something stupid on behalf of Denmark making Denmark close'

The employer representative believes that market-discipline under company-level wage bargaining is better than wage moderation under more centralized wage bargaining. Moreover, there is an express concern that centralized bargaining will get it wrong with macro-economic consequences while company level bargaining is an isolated matter. This is despite the fact that Denmark as a whole had lost cost competitiveness with its 
system. Clearly, the loss of cost competitiveness during the 2000s shows that 'mistakes' on wage setting at the company level can have macro-level consequences - but this story is absent in the employer's sensemaking.

As counterfactual cases of what would have happened in the absence of this story, we find Finland which opted for incomes policies to moderate wages (Sippola, 2015). In Finland, the causal story was: 'if we don't strengthen the control over company level bargaining, we will lose competitiveness'. However, the story has not been without counter-stories. Social partners and the government have been in political turmoil since the dominant employer confederation wanted to do away with tripartite incomes policies in 2011. This led to chaotic company level bargaining and wage-drift. Employers subsequently joined the government and the unions to re-instate tripartite incomes policies to moderate wages (Andersen et al., 2014). In 2015, the employer confederation decided to withdraw from tripartite bargaining again, but then returned to tripartite bargaining with the union confederation in 2016. Without going into detail with the Finnish story, it shows the ambiguity of markets and institutions and how sensemaking of the situation in Finland affected the actions taken in a different way than in Denmark.

Sensemaking in general involves highlighting differences between 'our way of doing things' and 'others' way of doing things'. In this quote, an employer representative explains the difference between institutionalized wage moderation in Norway and the 
Danish wage bargaining system - equating the Norwegian way with how things were done in the past in Denmark.

'Taking Norway as an example of what we in Denmark had in the beginning of the 1980s - sending out common decrees about what you [companies] can and cannot do [regarding wages]... ... as you can tell I'm a huge supporter of giving the labour market full responsibility of problems that might exist.

In this way, the Danish wage bargaining system is placed 'in front' of the Norwegian in terms of institutional development. The Norwegian is archaic - a thing of the Danish past. An additional quote shows how the sensemaking of the past is an important tool for sensemaking of the present:

'During many years we were out of step [concerning wage developments], and we didn't align until in 2000. We should not get out of step againand we won't. There has been so many [analysts] that have sat down and philosophised about what being out of step cost us in terms of wage increases... it ruined everything for us internally in the private sector, in relation to the finance sector and in relation to the public sector wage increases.'

The specific Danish way of bargaining wages with pattern-setting coordination around the manufacturing agreement is thus placed in time and as a natural outcome of a 
learning process; On one hand, the centralized system similar to Norway was too rigid for companies and took away responsibility from local players. On the other hand, uncoordinated bargaining as seen in the 1990s when bargaining rounds were not synchronized was also costly.

The causal story underlying the Danish advantage of a coordinated two-tier bargaining system appears in the next quote:

'It's a system that is capable of creating social capital, proximity and community in the companies because collective agreements are so open and local actors have to take responsibility'.

So, not only does markets discipline local wage bargaining, decentralisation of wage bargaining to the company level also creates social capital, proximity between workers and management and a sense of community. This causal story is akin to academic work by Per Hull Kristensen and colleagues that stress how workers are engaged in continuous improvements of work organisation due to a sense of community with the company (Kristensen, 2015). The employer representative couples this sense of community, i.e. the open collective agreements not only provide flexibility but also local responsibility and community feeling. Notice, that this coupling is quite a different portrayal of decentralised bargaining than commonly found among union officials who stress growing wage differentials. Arguably, actors from different positions will give different meanings to decentralisation to the company level. 
Sensemaking of wage bargaining thus cemented the existing institutions in Denmark. This is what Borrás and Seabrooke (2015:10) call 'belonging' by creating narratives that explain what happened in terms of cues and causal stories from embedded identities and social norms. The quotes from employer representatives stress the adequacy of past reforms, i.e. decentralization of collective bargaining to the company level, despite the loss of cost competitiveness in three ways: 1) loss of cost competitiveness is not due to the institutions but labour market shortages and taxation, 2) centralization is a thing of the past, 3) decentralization to company level entails learning through market-discipline which is superior to learning at confederate level bargaining, and 4) decentralization creates local communities at the workplace and therefore has positive spin-off effects on company performance.

As noted above, DI - representing 62,3 of DA's payroll - claims a key role in making sense of coordination. Its role is interesting, because from a purely market structural point of view, DI's members are the ones suffering most from the lack of wage moderation. So why didn't DI promote changes? Spanning manufacturing and service companies, DI, however, cannot afford to be myopic in how it represents its members. Moreover, the organization is so big that it also has to make sure that other organisations don't feel stepped on when collective action is needed. As Fligstein (2001) suggests, strategic actions are often motivated by a need for cooperation in the face of ambiguity and raw coercion will most often be a short-sighted solution even for 
dominant actors like DI. In the next quote, DI acts to preserve the sense of community among other employer representatives and secure collective actions by being pragmatic: '... I think that DI also listens. You can move them and I believe that they guard the community more than previously. Previously, they would go-italone more than they do now and I think that they have learnt not to bully because they don't win anything from it. Of course, we also have to be good when we speak to DI-people, present our arguments and the challenges. So, I think they can be moved.'

Securing alliances for the future is an integrated part of being the dominant player among the employer associations. The quote shows that dominance is backed up by legitimacy, i.e. that DI is an organization that will listen to arguments and specific concerns of other employer associations. Hereby, DI takes on a systemic responsibility of keeping the community together - not least because the community serves the interests of DI. Listening and deliberating with other employer associations, nonetheless, has limits. The negotiations over the equal pay committee in 2010 is a good example. The issue was delegated to DA and LO but the confederations came to a stalemate. First going through the ropes of listening and being pragmatic, DI then went alone with its direct bargaining partner, CO-industry (a bargaining cartel for manufacturing unions). The point is that DI had to listen and be pragmatic before goingit-alone to preserve the legitimacy in the employer community. 
The quotes together give the impression that the economic recession and the cost competitiveness problem in Denmark did not give rise to any serious discussions among employers about reforming wage bargaining institutions. Indeed, the causal story about local wage bargaining and competitiveness was not seriously challenged except on two occasions in 2010 and 2014 when employers in the meat processing industry challenged the status quo by demanding that DI do away with minimum wages in their area due to low wage competition from Germany. DI - representing the meat processing employers - again had to keep collective action together by being skillful negotiators. This was done on one hand by presenting unions with a cautious demand of doing away with minimum wages, and on the other hand respecting that the unions would never accept to leave meat processing workers behind. Hereby, the dominant organization had represented its member employers loyally but preserved collective action on wages and thus maintained status quo.

\section{Concluding remarks}

This paper argues that the preferences of employers for collective action cannot be reduced to rational actors making decisions based on market structures or institutional logics. Both markets and institutions are inherently ambiguous (Parsons, 2007; Streeck and Thelen, 2005) and employers therefore have to settle for plausible - rather than accurate - rational strategies among many alternatives through so-called sensemaking. 
Sensemaking refers to the process by which employers continuously make sense of their competitive environment by building causal stories of competitive advantages (Porac et al., 1989; Borrás and Seabrooke, 2015). The paper therefore tries to provide a better understanding of how preferences for collectivism are formed, sustained and potentially changed by identifying dominant and competing stories that either reinforce or challenge preferences for collectivism. Analysing quotes from interviews with Danish employer representatives, the paper illustrates how a specific sensemaking prevented employers from pursuing changes of the wage bargaining system despite the system's failure to produce wage moderation. Employer associations have a key role in coordination that moderates wages, but this role had clearly failed. Using causal stories that located the problem of cost competitiveness outside the system, however, coordination and the bargaining system was 'off the hook'. The analysis also shows how the most powerful employer association, DI, skilfully sustained this story. The introduction of sensemaking can inform analysis of employer collectivism in three ways. First, it takes ambiguity of institutions and markets seriously and shows how actors solve ambiguity. Due to the recession, Danish employers - like employers elsewhere - woke up to a new reality that researchers and practitioners are still trying to grasp. How collective action improves or deteriorates competitive advantage in this new reality is still not clear, but dominant actors in Denmark, so far, have cemented the existing causal story about coordinated wage bargaining. Second, analysis of quotes 
from employer representatives and how they made sense of employer collectivism visà-vis the crisis gives us an indication of where employer collectivism is going. The quotes in this paper reveal a path dependent logic, that is, the collective bargaining system is believed to be able to solve the challenges stemming from the recession. The absence of a competing causal story to how the deteriorated Danish cost competitiveness should be solved holds the bargaining system together (for accounts where the causal story changed see Culpepper, 2008 and Foster et al. 2011). Third, sensemaking makes the analysis attuned to how strategic actions are often about persuading and listening in the face ambiguity. Dominant actors thrive not only from being powerful in terms of resources but also from being seen as legitimate. Methodologically, the sensemaking analysis requires something different from the researcher. First, it requires qualitative data in which employers are allowed to reflect on collectivism together with the interviewer. This is a tall - but not impossible - order (Brinkmann, 2007). Certainly, some respondents will happily self-reflect. Second, it requires comparative case study of employers in different contexts, that is across market structures and institutional settings. Third, the treatment of data can be comprised in narrative analysis of causal stories of competitiveness, that is how actors see employer collectivism being a cause - or impediment - of competitiveness.

To be sure, these theoretical and methodological ways to inform analysis by no means negate the importance of institutions and market structures. Institutions and market 
structures should be analytical elements in a sensemaking analysis. But just as social scientists engage in concept formation and definitions to make sense of social phenomenon, so do social actors. By grounding the sensemaking analysis in rigorous institutional and structural analysis we could get the best of all worlds (cf. Parsons, 2007). The analytical challenge is how to disentangle how specific institutions and market structures and changes thereof leave actors with ambiguity. Evidently, ambiguity is most prevalent during some sort of crisis, but as many scholars have now argued, ambiguity is endemic. As an analytical tool sensemaking gives us an opportunity to understand how actors deal with this endemic feature of the social world and more specifically to understand why employers chose to be a member of a collective organisation and what being a member means to them.

\section{References}

Andersen SK, Dølvik JE and Ibsen CL. (2014) Nordic labour market models in open markets. Brussels: ETUI.

Barry M and Wilkinson A. (2011) Reconceptualising employer associations under evolving employment relations: countervailing power revisited. Work, Employment \& Society 25: 149-162.

Blyth M. (2003) Structures Do Not Come with an Instruction Sheet: Interests, Ideas, and Progress in Political Science. Perspectives on Politics 1: 695-706. 
Borrás S and Seabrooke L. (2015) Sources of National Institutional Competitiveness -

Sensemaking in Institutional Change. In: Borrás S and Seabrooke L (eds) Sources of National Institutional Competitiveness - Sensemaking in Institutional Change. Oxford: Oxford University Press, 1-19.

Brinkmann S. (2007) Could Interviews Be Epistemic?: An Alternative to Qualitative Opinion Polling. Qualitative Inquiry 13: 1116-1138.

Calmfors L and Driffil J. (1988) Bargaining Structure, Corporatism, and Macroeconomic Performance. Economic Policy 6: 13-61.

Campbell, J. L., \& Pedersen, O. K. (Eds.). (2001). The Rise of Neoliberalism and Institutional Analysis. Princeton: Princeton University Press.

Carstensen MB. (2010) The Nature of Ideas, and Why Political Scientists Should Care:

Analysing the Danish Jobcentre Reform from an Ideational Perspective. Political Studies 58: 847-865.

Culpepper, P. D. (2008). The Politics of Common Knowledge: Ideas and Institutional Change in Wage Bargaining. International Organization, 62(1), 1-33.

DA. (2014) Arbejdsmarkedsrapport 2014. København.

Due J, Madsen JS, Strøby Jensen C, et al. (1994) The Survival of The Danish Model, Copenhagen: DJØF's Forlag.

Fligstein N. (2001) Social Skill and the Theory of Fields. Sociological Theory 19: 105-125. Fligstein N and McAdam D. (2012) A Theory of Fields, Oxford: Oxford University Press. Foster, B., Rasmussen, E., Murrie, J., \& Laird, I. (2011). Supportive Legislation, Unsupportive Employers and Collective Bargaining in New Zealand. Relations Industrielles / Industrial Relations, 66(2), 192-212. 
Frege, C. (2005). The discourse of industrial democracy: Germany and the US revisited Economic and Industrial Democracy, 26(1), 151-175.

Friedland R and Alford RR. (1991) Bringing Society Back In: Symbols, Practices, and Institutional Contradictions. In: DiMaggio PJ and Powell WW (eds) The New Institutionalism in Organizational Analysis. Chicago: The University of Chicago Press, $232-263$

Goul Andersen J. (2014) Krisen uden ende? - Forkerte diagnoser og fejlslagen krisepolitik i Danmark. In: Ibsen CL and Høgedahl L (eds) Økonomi og Arbejde i det 21. århundrede - Et festskrift til Flemming Ibsen. København: Jurist- og Økonomforbundets Forlag, 337-356.

Hall P, A. and Soskice D. (2001) Varieties of Capitalism: The Institutional Foundations of Comparative Advantage. Oxford: Oxford University Press.

Hall P, A. and Taylor R, C.,R. (1996) Poltical Science and the Three New Institutionalisms. Political Studies 44: 936-957.

Ibsen C, L., Due J and Madsen JS. (2014) Fald i organisationsgraden igen. København.

Ibsen CL. (2011) Strained Compromises? Danish Flexicurity During Crisis. Nordic Journal of Working Life Studies 1: 45-65.

Ibsen, C. L. (2015). The Role of Mediation Institutions in Sweden and Denmark after Centralized Bargaining. British Journal of Industrial Relations, doi:10.1111/bjir.12142 Økonomi og Indenrigsministeriet. (2013) Økonomisk Redegфrelse - August 2013. Copenhagen: Økonomi og Indenrigsministeriet. 
Iversen T. (1999) Contested Economic Institutions. The politics of macroeconomics and wage bargaining in advanced democracies, Cambridge: Cambridge University Press.

Katz HC. (1993) The Decentralization of Collective Bargaining: A Literature Review and Comparative Analysis. Industrial and Labor Relations Review 47: 3-22.

Kitschelt HP, Lange P, Marks G, et al. (1999) Continuity and Change in Contemporary Capitalism. Cambridge: Cambridge University Press.

Korpi W. (2006) Power Resources and Employer-Centred Approaches in Explanations of Welfare States and Varieties of Capitalism: Protagonists, Consenters, and Antagonists. World Politics 58: 167-206.

Kristensen PH. (2015) Productive Enterprise in Search of a Regime: Moving Sensemaking from Past Phantom Communities to 'Ends in Sight'. In: Borrás S and Seabrooke L (eds) Sources of National Institutional Competitiveness - Sensemaking in Institutional Change. Oxford: Oxford University Press, 41-59.

Madsen JS, Due J and Andersen SK. (2016) Employment Relations in Denmark. In: Bamber GJ, Lansbury RD, Wailes N, et al. (eds) International and Comparative Employment Relations: Globalisation, Regulation and Change. London: SAGE, 208-236.

March J, G. (2010) The ambiguities of experience, Ithaca, NY: Cornell University Press.

Martin CJ and Swank D. (2012) The Political Construction of Business Interests: Coordination, Growth, and Equality, Cambridge: UK: Cambridge University Press.

Näslund L and Pemer F. (2012) The appropriated language: Dominant stories as a source of organizational inertia. Human Relations 65: 89-110. 
Olson M. (1965) The Logic of Collective Action: Public Goods and the Theory of Groups, Massachusetts: Harvard University Press.

Parsons C. (2007) How to Map Arguments in Political Science, Oxford: Oxford University Press.

Pierson P. (2004) Politics in Time - History, Institutions and Social Analysis, Princeton, NJ: Princeton University Press.

Porac JF, Thomas H and Baden-Fuller C. (1989) Competitive Groups As Cognitive Communities: The Case Of Scottish Knitwear Manufacturers. Journal of Management Studies 26: 397-416.

Schmidt VA. (2010) Taking ideas and discourse seriously: explaining change through discursive institutionalism as the fourth 'new institutionalism'. European Political Science Review : EPSR 2: 1-25.

Schmitter PC and Streeck W. (1999) The Organization of Business Interests: Studying the Associative Action of Business in Advanced Industrial Societies. Köln: MPIfG Discussion Paper 99/1.

Sheldon P, Nacamulli R, Paoletti F, et al. (2014) Employer Association Responses to the Effects of Bargaining Decentralization in Australia and Italy: Seeking Explanations from Organizational Theory. British Journal of Industrial Relations: 54: 160-191

Sippola M. (2015) Collective agreements versus legislation from the perspective of values: The case of Finland. Copenhagen: Foreningen Norden.

Sisson K. (1987) The Management of Collective Bargaining, Oxford: Basil Blackwell. 
Streeck W and Thelen K. (2005) Introduction: Institutional Change in Advanced Political Economies. In: Streeck W and Thelen K (eds) Beyond Continuity. Oxford: Oxford University Press, 1-39.

Tolliday S and Zeitlin J. (1991) Introduction. In: Tolliday S and Zeitlin J (eds) The Power to Manage? Employers and Industrial Relations in Comparative Historical Perspective. London: Routledge, 1-34.

Traxler F. (2007) The theoretical and methodological framework of analysis. In: Traxler F and Huemer G (eds) Handbook of Business Interest Associations, Firm Size and Governance - A comparative analytical approach. London: Routledge, 10-35.

Wailes N, Ramia G and Lansbury RD. (2003) Interests, Institutions and Industrial Relations. British Journal of Industrial Relations 41: 617-637.

Weber K and Glynn MA. (2006) Making Sense with Institutions: Context, Thought and Action in Karl Weick’s Theory. Organization Studies 27: 1639-1660.

Weick KE. (1995) Sensemaking in Organizations, Thousand Oaks, California: SAGE Publications.

Weick KE, Sutcliffe KM and Obstfeld D. (2005) Organizing and the Process of Sensemaking. Organization Science 16: 409-421.

Windmuller JP and Gladstone A. (eds) (1984) Employers Associations and Industrial Relations - A Comparative Study. Oxford: Clarendon Press. 